\title{
STUDY KASUS BODY IMAGE PADA SISWA DI SMA NEGERI 1 GROBOGAN
}

\author{
Oleh; \\ Nurulistyawan $^{1)}$, Rahmawati ${ }^{2)}$, Ike Diah Ayu Larasati ${ }^{3)}$ \\ 1) Dosen STIKES An Nur Purwodadi, Email; nurulistyawan.tp@gmail.com \\ 2) Dosen STIKES An Nur Purwodadi, Email; wrahma976@gmail.com \\ 3) Mahasiswa Keperawatan STIKES AnNurPurwodadi, Email: iikee6652@gmail.com
}

\begin{abstract}
ABSTRAK
Latar Belakang: Citra tubuh merupakan komponen yang paling penting dalam hidup manusia (Husna, 2013). Gambaran citra tubuh pada remaja putri, sebesar 45,2\% dan laki-laki $35 \%$, sehingga keinginan untuk menurunkan berat badan lebih banyak terjadi pada putri 37,6\% dibandingkan laki-laki 37\% (Merinta, 2012). Hal ini mendorong remaja dengan obesitas untuk memperbaiki penampilan fisik, khususnya berat badan dengan cara mengatur pola makan yang baik. Tujuan dari penelitian ini adalah untuk mengetahui body image pada siswa di SMA Negeri 1 Grobogan.
\end{abstract}

Metode: Penelitian ini merupakan penelitian studi kuantitatif dengan menggunakan pendekatan crossectional, populasi dalam penelitian ini adalah siswa SMA Negeri 1 Grobogan yang mengalami obesitas. Teknik sampling yang digunakan adalah probability sampling dan diperoleh sampel sebanyak 91 orang. Uji Hipotesis menggunakan univariat menggunakan Analisis Statistik.

Hasil: Hasil penelitian ini diperoleh hasil body image positif sebanyak $62(68.1 \%)$ responden dan body image negatif sebanyak 29 (31.9\%) responden.

Simpulan: Dari hasil penelitian ini dapat disimpulkan bahwa body image pada siswa SMA Negeri 1 Grobogan adalah body image positif.

Kata Kunci : Body image, Remaja 


\title{
CASE STUDY OF BODY IMAGE ON STUDENTS OF SMA NEGERI 1 GROBOGAN
}

Oleh;

Nurulistyawan $^{1)}$, Rahmawati $^{2)}$, Ike Diah Ayu Larasati ${ }^{3)}$

1) Lecturer of STIKES An Nur Purwodadi, Email; nurulistyawan.tp@ gmail.com Lecturer of STIKES An Nur Purwodadi, Email; wrahma976@gmail.com

2) Nursing Students of STIKES AnNurPurwodadi, Email: iikee6652@gmail.com

\begin{abstract}
Background: Body image was the most important component in human life (Husna, 2013). Perception of body image in adolescent girls was equal to 45,2\% and in men was equal to $35 \%$, it makes the girls have tendency to lose their weight (37,6\%) comparing to the men (37\%) (Merinta,2012). This encourages adolescents with obesity to maketheir physical appearance better,especially something dealing with their weight by managing a good eating pattern. The purpose of this study was to determine the body image on students in SMA Negeri 1 Grobogan.

Method: This research was a quantitative study using cross-sectional approach, the population in this study were students of SMA Negeri 1 Grobogan who were obese. Sampling technique used probability sampling with sample of 91 people. Statistical Analysis were analys used univariate.
\end{abstract}

Result: The result of this research was there were a study obtained 62 positive body image results (68.1\%) of respondents and negative body image of 29 (31.9\%) respondents

Conclusion: This study can be concluded that the body image of the students of SMA Negeri 1 Grobogan was the positive body image.

Keywords : Body image, Adolescent 


\section{PENDAHULUAN}

Citra tubuh merupakan komponen yang paling penting dalam hidup manusia (Husna, 2013). Gambaran citra tubuh pada remaja putri, sebesar $45,2 \%$ dan laki-laki $35 \%$, sehingga keinginan untuk menurunkan berat badan lebih banyak terjadi pada putri $37,6 \%$ dibandingkan laki-laki 37\% (Merinta, 2012). Hal ini mendorong remaja dengan obesitas untuk memperbaiki penampilan fisik, khususnya berat badan.

Berdasarkan hasil penelitian dari Tarigan (2007), pada 191 remaja obesitas di Yogyakarta sebanyak $91 \%$ memiliki citra tubuh negatif. Setyorini (2010), mengemukakan $51,6 \%$ remaja puas terhadap bentuk tubuhnya, sedangakan $48,4 \%$ tidak puas denngan bentuk tubuhnya. Dari penelitian yang dilakukan Miguel (2008), 1198 remaja obesitas di Portugal sebanyak 52,3\% mengalami masalah citra tubuh negatif, sedangkan hasil penelitian dari Pameswari (2013), terdapat 51,9\% remaja dengan citra tubuh negatif dan remaja dengan citra tubuh positif sebesar $48,1 \%$, sehingga banyak remaja yang memiliki citra tubuh negatif akibat obesitas.

Menurut data dari WHO (2016), 39\% wanita dan laki-laki berumur 18 tahun mengalami kegemukan. Berdasarkan hasil laporan dari Kemenkes RI (2017), secara nasional prevalensi kekurusan (IMT/U) yaitu $3,7 \%$ sangat kurus, $8,9 \%$ kurus, $83,1 \%$ normal, dan kegemukan sebesar 4,3\%. Data prevalensi (IMT/U) di Provinsi Jawa Tengah yaitu 2,7\% sangat kurus, $8,1 \%$ kurus, $85,5 \%$ normal, $3,6 \%$ gemuk.

Hasil analisa yang dilakukan oleh Mochamad (2014), siswa yang sangat kurus sebanyak 8 anak (2\%), siswa yang kurus sebanyak 17 anak (3\%), siswa yang dikatakan normal sebanyak 378 anak (75\%), siswa yang dinyatakan gemuk sebanyak 94 anak (18\%) dan siswa yang mengalami obesitas sebanyak 11 anak (2\%). Salah satu faktor yang menyebabkan anak mengalami obesitas adalah pola makan yang kurang baik (Rizki, 2015).

Penelitian ini diperkuat oleh Pusparini (2013), tentang persepsi citra tubuh remaja dengan sebagian besar responden menyatakan ketidakpuasan bentuk tubuh yang diinginkannya. Penelitian dari Pujiati (2015), tentang perilaku makan dengan status gizi pada remaja diperoleh $39,1 \%$ perilaku makan baik dan $60,9 \%$ perilaku makan kurang baik.

Penelitian yang dilakukan Tarigan (2007), remaja obesitas tidak puas dengan citra tubuhnya dari pada remaja yang tidak obesitas. Remaja perempuan obesitas lebih tidak puas terhadap citra tubuhnya dibandingkan remaja laki-laki yang mengalami obesitas.

Studi pendahuluan yang dilakukan pada tanggal 10 Januari 2018 di SMA N 1 
Grobogan didapatkan jumlah sebanyak 995 siswa, yang terdiri dari siswa putri 629 orang dan siswa putra 366 orang. Peneliti mengambil sampel 10 siswa untuk dilakukan observasi, terdapat 5 siswa yang mempunyai indeks massa tubuh tidak normal, 3 siswa diantaranya mempunyai kebiasaan makan yang baik dan 2 siswa sisanya mempunyai kebiasaan makan yang kurang baik sedangkan dari 5 siswa yang mempunyai indeks massa tubuh normal semua siswa mempunyai kebiasaan makan yang baik. Dari 5 siswa yang mempunyai indeks massa tubuh tidak normal terdapat 3 siswa yang mempunyai body image positif dan 2 siswa yang mempunyai body image negatif sedangkan 5 siswa yang mempunyai indeks massa tubuh normal semuanya mempunyai body image positif.

\section{METODE}

Desain peneltian yang digunakan adalah Cross Sectional yaitu suatu penelitian survey analitikyang mempempelajari tentang dinamika korelasi antara faktor-faktor resiko dengan efek, dengan cara pendekatan, observasi atau pengumpulan data secara bersama-sama pada saat itu juga (point time approach) yang artinya tiap subyek penelitian hanya diobservasi sekali saja dan pengukuran dilakukan terhadap status karakter atau variabel subyek pada saat pemeriksaan (Notoatmodjo, 2012).
Teknik sampling yang digunakan pada penelitian ini adalah Probability sampling dengan teknik sampel stratified random sampling yaitu pengambilan sampel dari masing-masing strata yang dilalukan secara acak (Riyanto, 2011).

Jumlah sampel yang digunakan dalam penelitian ini sebanyak 91 responden.Variabel independen dalam penelitian ini adalah pola makan dan variabel dependen dalam penelitian ini adalah body image. Metode pengumpulan data yang digunakan dalam penelitian ini adalah kuesioner. Alat pengukuran yang digunakan dalam penelitian ini adalah kuesioner pola makan dan kuesioner body image.

\section{HASIL PENELITIAN}

\section{A. Gambaran Umum Lokasi}

Lokasi penelitian dilaksanakan di Sekolah Menengah Negeri 1 Grobogan Kecamatan Grobogan Kabupaten Grobogan. SMA N 1 Grobogan adalah sekolah menengah negeri memiliki pemerintah daerah dan SMA N 1 Grobogan, merupakan pendidikan formal yang terletak di Kecamatan Grobogan, terdiri dari 1 Kepala Sekolah, 56 Tenaga Pengajar, dan terdapat 34 ruangan yang terdiri dari 1 Ruang Kepala Sekolah, 2 Ruang Guru, 27 Ruang Kelas, 3 Laboraturium, 1 Perpustakaan. Rata- 
rata murid yang bersekolah di SMA N

1 Grobogan usianya 16 tahun sampai

17 tahun, dan pembelajaran dimulai dari pukul 07.00 WIB hingga pukul 15.30 WIB.

\section{B. Analisa Univariat}

Tabel 1; Distribusi Body Image Obesitas Siswa SMA

\begin{tabular}{lll}
\hline Body Image & $(\mathbf{f})$ & $\mathbf{( \% )}$ \\
\hline Positif & 62 & 68.1 \\
Negatif & 29 & 31.9 \\
\hline \multicolumn{1}{c}{ Total } & $\mathbf{9 1}$ & $\mathbf{1 0 0}$ \\
\hline
\end{tabular}

\section{PEMBAHASAN}

Bedasarkan tabel diatas diketahui hasil body image pada 62 responden (68.1\%) mempunyai body image positif, sedangkan 29 responden (31.9\%) mempunyai body image negatif. Body image juga dapat diartikan sebagai sikap seseorang terhadap tubuhnya yang pengaruhi persepsi, imajinasi, emosi, suasana hati, lingkungan, dan pengalaman fisik yang dapat terjadi dalam bentuk body image remaja (Na'imah, 2008).

Body image dapat mengalami perubahan sepanjang rentan kehidupan sebagai tanggapan terhadap umpan balik yang berubah-ubah dari orang lain, lingkungan sosial dan budaya yang berlaku. Body image yang sehat ditandai dengan adanya gambaran mental dan sikap yang akurat tentang tubuh dan merupakan salah satu perwujudan dari harga diri yang positif. Apabila seseorang yang memiliki pemikiran tubuh yang positif, maka otomatis ia akan merasa puas dengan kondisi tubuh dengan apa adanya. Namun jika seseorang memiliki pemikiran tubuh yang negatif maka ia akan selalu membandingkan tubuhnya dengan tubuh ideal milik orang lain yang diinginkan dan selalu merasa tidak puas dengan kondisi tubuhnya (Cash dalam Pusparini, 2013).

Menurut Verawati, (2015) dengan judul relation body image with eating petterns and nutritional status of adloslescent girls in junior high school $\mathrm{Al}$ Islam 1 Surakarta. Hasil pengukuran body image yang telah dilakukan terhadap 60 responden diperoleh hasil bahwa sebanyak $41.7 \%$ mempunyai body image negatif dan sebanyak $58.3 \%$ mempunyai body image positif. Menurut penelitian Syahrir, (2013) menujukkan bahwa sebagian besar responden memiliki body image yang posotif (artinya menerima bentuk tubuh saat ini) yaitu $66.2 \%$ (47 orang) namun juga terdapat $33.8 \%$ (24 orang) responden yang memiliki persepsi body image negatif (artinya tidak menerima bentuk tubuh saat ini).

\section{DAFTAR PUSTAKA}

Husna. (2013). Hubungan Antara Body Image Dengan Perilaku Diet Di Sanggar Senam Rita Pati. Semarang. 
Kemenkes RI. (2017). Pusat Data dan Kementrian Kesehatan RI. (Boga \& Yudianto, Eds.). Jakarta.

Merinta. (2012). Hubungan Body Image, Pengetahuan Gizi Seimbang, dan Aktivitas Fisik Terhadap Status Gizi Mahasiswa Politeknik Kesehatan Jayapura.

Miguel. (2008). Body-Image and Obesity in Adolescence: A Comparative Study of Social-Demographic, Psychological, and Behavioral Aspects, 11(2), 551-563.

Mochamad. (2014). Prevalensi Obesitas Pada Anak Usia SD Menurut IMT/U Di Sd Negeri Ploso Ii No 173 Surabaya. Jurnal Pendidikan Olahraga Dan Kesehatan, 2(173), 114-118.

Na'imah. (2008). Pengaruh Komparasi Sosial Pada Public Figure Di Media Massa Terhadap Body Image Remaja Di kecamatan patikraja, kabupaten bayumas. Jurnal Psikologi Penelitian Humaniora, 9, 2.

Notoatmodjo. (2012). Metodelogi Penelitian Kesehatan. Jakarta: Rineka Cipta.

Prameswari. (2013). Hubungan Obesitas Dengan Citra Diri Dan Harga Diri Pada Remaja Putri Di Kelurahan Jomblang Kecamatan Candisari Senarang.Jurnal Keperawatan Komunitas, 1(1), 52-61.

Pujiati, Arneliwati, S. R. (2015). Hubungan antara perilaku makan dengan status gizi pada remaja putri.Program Studi Ilmu Keperawatan, Universitas Riau, 2, 2.
Pusparini, Refdanita, Tonny, \& Dodik. (2013). Studi Kualitatif Persepsi Citra Tubuh Remaja Yang Kurus Dan Gemuk Serta Upaya Untuk Mencapai Tubuh Ideal Pada Siswi Sma Negeri 1 Kota Bogor. Studi Kualitatif Persepsi Citra Tubuh Remaja, 6, 15-28.

Riyanto. (2011). Aplikasi Metodelogi Penelitian Kesehatan. Yogyakarta: Nuha Medika.

Rizki. (2015). Hubungan Antara Pola Makan Dengan Kejadian Obesitas Pada Anak Usia 7-12 Tahun Di SD Mardi Rahayu Ungaran Kabupaten Semarang, 1-8.

Setyorini. (2010). Harga Diri dan Prestasi Belajar pada Remaja yang Obesitas.Jurnal Psikologi.

Syahrir. (2013). Program Studi Ilmu Kesehatan Fakultas Kesehatan Masyarakat, Universitas Hasanudin Makasar.Pengetahuan Gizi, Body Image, Dan Status Remaja Di SMA Islam Kota Makasar, 1-10.

Tarigan. (2007). Hubungan Citra Tubuh Dengan Status Obesitas, Ativitas Fisik, Dan Asupan Energi Remaja. Tesis. Program Pasca Sarjana Ilmu Kesehatan Masyarakat. Universitas Gajah Mada.

Verawati, R. (2015). Hubungan Antara Body Image Dengan Pola Makan Dan Status Gizi Remaja Putri Di SMP Al Islam 1 Surakarta.Study Of Nutrition Faculty of Health Muhammadiyah University Of Surakarta, 1-11.

WHO. (2016). Word Health Organization. Adolescentas Nutrition: A Review of the Situation in Selected South East Asian Countries. 